\title{
"Trasvasamiento generacional no es trasvasamiento ideológico". La revista Extra y el conflicto interno en el peronismo (1973-1974)
}

Generational transfer is not ideological transfer. The Extra magazine and the internal conflict in Peronism (1973-1974)

\author{
Micaela Iturralde \\ Consejo Nacional de Investigaciones Cientificas y Técnicas - \\ Universidad Nacional de Mar del Plata, Argentina \\ micaelaiturralde@gmail.com
}

\author{
Marcelo Borrelli \\ Consejo Nacional de Investigaciones Cientificas y Técnicas - \\ Universidad Nacional de Buenos Aires, Argentina \\ marcebor@yahoo.com
}

\section{RESUMEN:}

Este artículo analiza el posicionamiento editorial de la revista Extra dirigida por Bernardo Neustadt frente al conflicto interno en el peronismo desde la asunción de Héctor Cámpora a la presidencia en mayo de 1973 hasta el fallecimiento del entonces presidente Juan Domingo Perón en julio de 1974. El objetivo es analizar discursivamente el tratamiento que dio a estas disputas, a la creciente radicalización política de sus facciones y al proceso de "depuración ideológica" contra su sector revolucionario de izquierda desde fines de 1973. El trabajo concluye que Extra intentó posicionarse como representante del "centro político", destacando el rol de Perón como eje para la "unidad nacional” y criticando a los sectores revolucionarios de la izquierda peronista.

Palabras Clave: Peronismo, Revista Extra, Bernardo Neustadt, Perón, Montoneros.

\section{ABSTRACT:}

This article analyzes the editorial positioning of the magazine Extra directed by Bernardo Neustadt against the internal conflict in Peronism since the assumption of Héctor Cámpora to the presidency in May 1973 until the death of the then president Juan Domingo Perón in July 1974. The objective is to discursively analyze the treatment that gave rise to these disputes, to the growing political radicalization of their factions and to the process of "ideological depuration" against their leftist revolutionary sector since the end of 1973. The paper concludes that Extra tried to position itself as representative of the "political center", highlighting the role of Perón as the axis for "national unity" and criticizing the revolutionary sectors of the Peronist left.

KEYWORDS: Peronism, Extra magazine, Bernardo Neustadt, Perón, Montoneros.

\section{INTRODUCCIÓN}

En Argentina, la década del setenta constituyó una "edad de oro" para los medios de comunicación en general y la prensa política en particular. El mercado periodístico de estos años era amplio, diversificado y altamente competitivo, jalonado por un crecimiento económico inusitado y por el inicio de la radicalización y el aumento de la participación popular en la política. ${ }^{2}$ El consumo de algunos bienes culturales, como diarios, revistas y libros, además de las crecientes audiencias que concitaban la radio y la televisión, estaba muy extendido entre las clases medias que tenían hábitos de lectura bien consolidados.

En estos años existía una veintena de revistas que superaba la tirada de 50 mil ejemplares. El mercado era liderado por publicaciones como Gente, Así, Siete Días, La Semana, Semana Gráfica, Radiolandia, Antena, TV Guia, Vosotras, Labores, Para Ti y Claudia. Entre las infantiles, Anteojito, Billiken y Las locuras de 
Isidoro eran las más populares en ventas (Becerra, 2010). En el sector de las revistas de actualidad política, se destacaban Panorama, Confirmado, Primera Plana, Redacción, Extra y Carta Política, entre otras. Si se tiene en cuenta que la prensa gráfica era aún el medio de comunicación masiva más popular, se comprende con facilidad la posición estratégica en la que se encontraban las revistas políticas. El alto grado de politización hacía de ellas un instrumento fundamental para los debates políticos, lo que las convertiría en un escenario privilegiado para las disputas de poder entre diferentes grupos.

Este trabajo se propone analizar en particular a la revista Extra y su posicionamiento editorial frente al conflicto interno en el peronismo desde la asunción de Héctor Cámpora a la presidencia en mayo de 1973 hasta el fallecimiento del entonces presidente Juan Domingo Perón en julio de 1974. El interés está dado por conocer y explicar el modo en que dicha publicación ofreció tratamiento a las disputas internas del peronismo, la creciente radicalización política de sus facciones y el proceso de "depuración ideológica" experimentado dentro del movimiento contra su sector revolucionario de izquierda desde fines de 1973.

¿Cómo fue recibido el retorno del peronismo por una revista como Extra?, ¿cuál fue su posicionamiento respecto de la fractura del peronismo?, ¿qué interpretación elaboró la publicación sobre la figura de Perón y su rol en la coyuntura?, ¿qué transformaciones experimentó su postura editorial en relación a las diferentes fases del enfrentamiento dentro del movimiento? Son algunos de los principales interrogantes que organizan la presente indagación.

El artículo propone un análisis centrado en la producción discursiva y se inscribe dentro de la tradición de análisis crítico del discurso (van Dijk, 1990), entendida como una sociosemiótica que analiza las prácticas sociales de producción y reconocimiento de significados en una comunidad determinada. En este caso, nos situamos en el análisis discursivo de una publicación periódica, teniendo en cuenta sus condiciones de producción y el contrato de lectura propuesto por la revista a un público particular (Verón 1985). En consecuencia, se establecerán las condiciones históricas y sociales en las que la enunciación de Extra tuvo lugar y se explicitarán los vínculos establecidos por el medio y su director con el poder político y económico de su época. El corpus elegido, organizado a partir de un criterio cronológico, está compuesto por los editoriales y las notas de opinión firmadas por el director de la publicación. Tales secciones expresan la voz institucional de un medio de prensa, dado que constituyen el espacio en el que se resume el posicionamiento de la publicación y en el que se sistematizan su línea política e ideológica (Castelli, 1991).

\section{EXTRA: PERFIL EDITORIAL de LA PUblicación y DE SU DIRECTOR BERNARDo NeUstadT}

Extra fue una revista de aparición mensual dirigida por el periodista Bernardo Neustadt y publicada por editorial El País entre julio de 1965 y mayo de 1989. Fue fundada con el objetivo de abordar temas relacionados con la política, la economía y el plano internacional y se integró al entramado multimediático del periodista que para la década de 1970 ya incluía medios gráficos, radiales y televisivos.

Sin duda fue la voz y el particular estilo periodístico de su director lo que le otorgó a Extra su perfil ideológico definido. La asistematicidad en ciertas temáticas, sus posiciones editoriales atravesadas por el personalismo, la omnipresencia del periodista y la influencia de la coyuntura y el pragmatismo antes que los análisis de largo plazo fueron algunos de los rasgos destacados de la publicación. La presencia de Neustadt puede ser observada en toda la superficie redaccional, a partir de la publicación de su firma y fotografía en los editoriales, en los textos que introducían cada número o en las notas de opinión sobre temas coyunturales. Asimismo, su impronta personal se vio reforzada por un fenómeno de circulación discursiva por el cual el director reproducía en Extra editoriales y textos extraídos de otros medios propios. Esto ocurría con lo publicado en el mensuario Creer (1975-1984), destinado al mundo empresarial y de los negocios y, especialmente, con las entrevistas desgrabadas de su programa televisivo Tiempo Nuevo, que le granjeó su popularidad y que estuvo al aire, con algunas interrupciones y cambios de canal, por más de tres décadas. 
Nacido en 1925 en Rumania cuando su padre trabajaba en la embajada argentina en ese país, Bernardo Neustadt llegaría a ser una de las figuras más consagradas del periodismo gráfico y televisivo argentino del siglo XX. Cuando a mediados de la década de 1960 emprendió Extra, Neustadt tenía ya más de 20 años ejerciendo la profesión periodística. Había ingresado al diario El Mundo siendo sólo un joven de quince años y luego entró como cronista en la revista deportiva Racing, en la que se desempeñaría como Secretario de Redacción. Durante el primer peronismo, además de su labor periodística, desempeñó varios cargos de gobierno. Fue secretario privado del almirante Alberto Teisaire ${ }^{3}$-a quien conoció por su tarea como cronista parlamentario en la revista satírica $P B T$-, jefe de prensa del Consejo Superior del Partido Peronista y secretario general y director general de "Relaciones con las Organizaciones del Pueblo"4 (Bonasso, 1997: 82; Bosoer, 2013 : 222-229; Neustadt, 1995; Fernandez Díaz, 2018).

A partir de 1955, con el derrocamiento de Perón, su actividad como funcionario del régimen fue cuestionada y sometida a investigación por las comisiones a tal efecto creadas por el nuevo gobierno militar autodenominado "Revolución Libertadora". Una vez recuperada su libertad, Neustadt iniciaría un rápido proceso de desperonización y, más posteriormente, de traspaso a las filas antiperonistas. Antes de promover sus propios proyectos editoriales, pasó por las redacciones de Clarín y regresó a El Mundo. En 1960 inició su incursión en la televisión, medio en el que con el correr de los años encontraría gran reconocimiento público. ${ }^{6}$

En octubre de 1964, Neustadt lanzó su primera revista política, concebida como su gran apuesta profesional. El semanario de actualidad Todo(Taroncher, 2009) representaba con claridad sus ambiciones de disputar el reconocimiento público y la masa de lectores a los proyectos editoriales de Jacobo Timerman, quien sería uno de sus principales rivales en el campo periodístico. Aunque la revista se editó sólo durante siete meses, esta experiencia fallida se revelaría fundamental en tanto antecedente editorial inmediato de Extra.

Ambos proyectos editoriales respondían a las necesidades de su director de constituir espacios de interpretación -e interpelación- del campo político nacional. A pesar de las dificultades que le había implicado su relación estrecha con el peronismo luego de 1955, Neustadt fue siempre un hombre cercano al mundo de la política y al establishment de su época. Sus contactos con el Estado y con grandes empresas nacionales e internacionales le permitieron construir una lucrativa cartera de auspiciantes para sus emprendimientos periodísticos, como se observa en las publicidades de sus revistas y programas televisivos. En ellos pautaban empresas como Techint y Acindar; bancos como el Español, el Popular Argentino, el de Intercambio Regional, el Provincia; firmas reconocidas como Austral, Philips, Siemmens, Olivetti; marcas de cigarrillos o whisky como Parisiennes o Nicholson, y hoteles de lujo como el Alvear Palace Hotel y el Plaza Hotel.

Con una extensión que promediaba las cincuenta páginas, Extra se organizó en algunas pocas secciones fijas ("Editorial", "Extra íntimo") a las que le sucedían artículos firmados por colaboradores habituales, encuestas y entrevistas elaboradas por la misma publicación. Si bien, como en la mayoría de las revistas políticas del momento, el texto prevalecía por sobre la imagen, las fotografías, los fotomontajes y las ilustraciones eran un recurso fundamental de las tapas, impresas a color y caracterizadas por el uso de titulares polémicos y de alto impacto. Aunque no contamos con datos de su tirada para la época de estudio, dado que la revista no estaba suscripta al Instituto Verificador de Circulaciones, Carman (2015: 311) indica que en la década del 60 llegó a tener una tirada de 45 mil ejemplares. Sin embargo, Fernández Díaz (2018: 100) señala que la tirada de Extra "era casi siempre misteriosa y por lo general escasa" y que, vista en su integridad, "fue solo un buen negocio y nunca logró saltar el cerco" (Fernández Díaz, 2018: 99), en relación a que no logró competir con otras revistas de su rubro y a que su permanencia en el mercado se debió más a los anuncios con los que contaba y a la fama de su director que a un gran número de lectores. Pero lo que era evidente -como lo ponía de manifiesto sus anuncios publicitarios, su temario, las personalidades entrevistadas y el destinatario explícito de las alocuciones del director- es que Extra era una publicación destinada al poder político y económico de la Argentina de las décadas de 1960 y 1970, que también intentó "hablarle" a un ciudadano con interés por los temas políticos, financieros e internacionales. 
En los inicios del proyecto editorial de Extra, su redacción contó con una destacada diversidad en la extracción política e ideológica de sus periodistas, entre los que se podían encontrar marxistas, peronistas, radicales, nacionalistas, liberales y frondizistas. En la primera redacción convivieron perfiles políticos y profesionales tan disímiles como los de Miguel Bonasso o Dardo Carbo (ligados a la izquierda peronista), junto con José Miguel Tarquini o Héctor Simeoni (provenientes de la derecha peronista y el nacionalismo católico, respectivamente).

Con los años, y ya para la etapa que analizamos en este artículo, esa diversidad dio paso a un perfil más homogéneo en el que se destacaron como colaboradores habituales las figuras de Miguel Gazzera (dirigente sindical peronista, miembro fundador de las 62 Organizaciones Peronistas), Jorge Aguado (político y representante del agro, quien sería funcionario de la dictadura en los años 1981-1982), Raúl Cuello (economista), Ricardo Zinn (autor intelectual del "Rodrigazo", asesor del ministro de Economía de la dictadura José Martínez de Hoz y ligado a los círculos liberales más intransigentes), Osiris Villegas (militar de gran influencia en la política de las décadas de 1950 y 1960, reconocido por su antiperonismo y anticomunismo), Carlos Cifuentes (filósofo mexicano, miembro del Opus Dei) y Clara Mariño (periodista que colaboró con Neustadt en su revista Creer y el programa televisivo Tiempo Nuevo). Por su parte, Reymundo Platti se desempeñó como subdirector de la publicación.

Vale entonces preguntarse, ¿qué elementos ideológicos caracterizaron el pensamiento político de Extra durante el período analizado?, ¿đe qué manera sus posicionamientos nutrieron sus proyectos periodísticos y otorgaron a la revista un perfil editorial definido y estable a lo largo de los años? Hacia la época bajo estudio, Neustadt fue precisando una particular posición política, concebida como una "ideología de centro" que se definía como una postura equidistante entre los extremos representados por la izquierda y la derecha y por el correspondiente rechazo tanto al marxismo como al liberalismo más ortodoxo. A partir de metáforas simples y de interpretaciones sencillas, caracterizadas por la debilidad teórica y la laxitud conceptual, la posición centrista elaborada por el periodista se sustentó en un discurso simultáneamente excluyente de la idea de un "socialismo nacional", tan en boga en esos años, como de un liberalismo de tipo fundamentalista con un Estado ajeno a los problemas sociales.

Dicha interpretación fue explicitada por el director en más de una ocasión durante el período analizado. En la nota de opinión titulada “'Ser de centro' será 'in”, publicada en la edición de noviembre de 1973, Neustadt explicaba que ser de centro no era ser conservador ni ser revolucionario, sino tener una "actitud reformista", intentar aplicar la "tolerancia intelectual y el realismo político", reconocer los conflictos pero no plantear soluciones paroxísticas o utópicas. Desde su perspectiva, el futuro de las sociedades pluralistas avanzaba hacia las posiciones centristas dado que eran las clases medias las que se sentían atraídas por el centro. Para el director de Extra, incluso los votantes de Perón de septiembre de 1973 y el propio Perón representaban tal postura diametralmente alejada de los extremos. ${ }^{7}$

\section{El RETORNO DEL PERONISMO AL PODER Y SU CONFLICTO INTERNO (1973-1974)}

El fin de la "Revolución Argentina" (1966-1973) estuvo marcado por la movilización popular y el reverdecer de las demandas sociales, la lucha armada contra el autoritarismo y el fracaso del Estado militar para conciliar los conflictos políticos, sociales y económicos que parecían alcanzar nuevamente el centro de la escena (Ollier, 2005). En este marco, en 1973 Perón parecía ser el único actor político con capacidad para restablecer el orden social y morigerar las reivindicaciones extremas de las organizaciones políticoarmadas -a las que había alentado desde su exilio madrileño-. Así lo entendieron incluso los militares responsables del gobierno que, alertados por el crecimiento de las demandas radicalizadas y la movilización popular, terminaron por restituir la legalidad a los partidos políticos, entre ellos al peronismo, y llamar a elecciones (Tortti, 1999). Aunque el líder del movimiento no pudo participar de los comicios del 11 de marzo de 1973 por un obstáculo legal pergeñado por los militares, eligió a su delegado, Héctor Cámpora, 
como su representante electoral. Cámpora contaba con el apoyo del peronismo de izquierda que, en un marco de alta participación popular, desempeñó un rol primordial en las elecciones que consagraron el triunfo del Frente Justicialista de Liberación (FREJULI) (Bonasso, 1997). ${ }^{8}$ En su corta estancia en el poder, asumió la presidencia el 25 de mayo y presentó su renuncia el 13 de julio de 1973, se vio asediado por las fuerzas contrapuestas presentes dentro del peronismo y por la desconfianza del propio Perón por su cercanía con la llamada Tendencia Revolucionaria, por entonces ya hegemonizada por la organización Montoneros (Csipka, 2013). ${ }^{9}$

Con su llegada al poder, las juventudes ligadas a la izquierda peronista experimentaron una verdadera "primavera política" que se expresó en un protagonismo sin precedentes de ese sector surgido al calor de la movilización antidictatorial (Manzano, 2017; Svampa, 2007). Sin embargo, el rechazo que motivaba entre la dirigencia sindical peronista la importancia otorgada al sector juvenil se volvió trágicamente visible el 20 de junio de 1973, fecha del regreso definitivo del líder al país, cuando la derecha del peronismo causó una verdadera masacre en Ezeiza al impedir que los simpatizantes de la Tendencia ocuparan posiciones cercanas al palco central (Verbitsky, 1998). A partir de entonces, en el seno del peronismo se abrió con toda contundencia la disputa entre los sectores de la "izquierda" del movimiento -representados por la Tendencia Revolucionaria, que proponían el "socialismo nacional"- y aquellos de la "derecha" -que propugnaban la "patria peronista” y estaban representados por la dirigencia sindical, los peronistas históricos, dirigentes diversos vinculados al nacionalismo de derecha y un grupo de reciente incorporación en torno al ministro de Bienestar Social, José López Rega- (Maceyra, 1983).

El discurso de Perón el día después de los acontecimientos de Ezeiza (Perón, 1974a: 49-52), dejaba en claro que el líder empezaba a alejarse de sus posiciones de antaño en defensa de la "juventud maravillosa" y las "formaciones especiales" y ahora, con la certeza de manejar los hilos del Estado nuevamente, pretendía disciplinar a los sectores revolucionarios que integraban el movimiento. Tal desplazamiento fue profundizado en los meses posteriores, y durante la tercera presidencia de Perón -iniciada el 12 de octubre de 1973- se abrió el camino para la generalización de una serie de medidas autoritarias, que fueron el preludio de la ofensiva conservadora que posteriormente encabezaría la derecha peronista contra los sectores revolucionarios de izquierda (peronista y no peronista), y contra el abanico de fuerzas populares que habían forjado el regreso del líder (Besoky, 2016; De Riz, 2010; Franco, 2012; Merele, 2017; Servetto, 2010; Svampa, 2007). Este desplazamiento de los sectores revolucionarios de izquierda se dio en el marco de un acercamiento de Perón a los partidos políticos de la oposición, fundamentalmente el radicalismo, y un discurso que fundaba el nuevo momento en la "unión nacional". Sin embargo, como señala Tcach (2002: 74-76), lo que había nacido con la "doctrina Ezeiza" era un "doble discurso", que junto a las apelaciones a la paz, la democracia y la unidad nacional convalidaba la impunidad para quienes desde el Estado -o desde las facciones amigas- se propusiesen eliminar al adversario político.

\section{EXTRA ANTE EL PROCESO ELECTORAL DE 1973}

Como era de esperar por la magnitud del hecho, el retorno del peronismo a la participación política luego de 18 años de proscripción despertó amplias expectativas en Extra. No por una repentina filiación de la revista al movimiento conducido por Perón, sino por su enrolamiento dentro del ya analizado imaginario de "centro" que rechazaba la radicalización ideológica, enfatizaba un discurso en defensa de las instituciones y de un capitalismo ordenado. En términos pragmáticos, Extra entendía que la "Revolución Argentina" ya estaba definitivamente "agotada", que una eventual continuación de la proscripción peronista significaría un "salto al vacío", con el riesgo de fabricar un enfrentamiento entre "civiles y militares", dar mayor pábulo a la radicalización política y a la "subversión” de izquierda. ${ }^{10}$ De manera que, durante la campaña presidencial para las elecciones del 11 de marzo, rodeada de rumores y acciones que hacían temer una nueva proscripción, la revista advirtió con insistencia acerca de la necesidad de preservar 
el proceso electoral y aceptar su resultado, sea cual fuere. En ese marco, dio cuenta con preocupación del accionar tanto de los sectores militares que, aunque los presentaba como minoritarios, se mostraban nuevamente dispuestos a interrumpir un proceso electoral frente a un triunfo peronista; ${ }^{11}$ de la "subversión", que seguía tratando de "ganarle a la elección” y de lo que llamó las "usinas golpistas", cuyo principal objetivo era, según esta interpretación, atemorizar a las clases medias y a los sectores militares y agitar un clima de "revanchismo", todo esto a fin de interrumpir los comicios. ${ }^{12}$

Luego del triunfo de Cámpora Extra exigió no "temerle a la verdad de la urna” y reconocer el triunfo del peronismo. ${ }^{13}$ Pero si bien aseguraba que se sabía "quién" había ganado, faltaba saber "quién gobernará", es decir, cuál sería la línea del nuevo gobierno y quién llevaría las riendas de la economía -si el desarrollismo, una línea más "reformista" o aquellos que planteaban el "socialismo nacional"-. Teniendo en cuenta el peso que había tenido la izquierda peronista en la campaña electoral del FREJULI, se preguntaba: "¿qué rol jugaran quienes reclaman un cambio total, convencidos de que el 11 de marzo, en las urnas, no hubo una elección sino una revolución y en consecuencia quisieran tocar el fondo mismo del sistema (...)?”. ${ }^{14}$ Su pregunta retórica apuntaba a uno de los conflictos clave que se iniciaban con el "gobierno popular".

La posición de Extra respecto de la influencia y el protagonismo alcanzados por la Tendencia Revolucionaria quedó plasmada tempranamente. Ya antes de la asunción de Cámpora el 25 de mayo, la revista denunció el "contrabando ideológico" que envolvía al peronismo, entendiendo por tal que el apoyo otorgado por amplios sectores de la juventud más radicalizada a los candidatos del movimiento y a su líder tenía por objetivo trastocar los pilares ideológicos peronistas hacia una versión de izquierda. Por eso planteaba que Perón tenía dentro de su movimiento a algunos "insubordinados" -a diferencia de los "disciplinados" que habían sido los seis millones de votantes-, quienes mientras él hablaba de "enlace de clases" ellos -en tanto "marxistas"- se enrolaban en el peronismo en nombre de la "lucha de clases". ${ }^{15} \mathrm{Al}$ respecto, argumentaba que “con el pretexto de 'trasvasamiento generacional” se intentaba el "trasvasamiento ideológico”, 16 acusando a estos sectores de "intrusos", "marxistas infiltrados" y "contrabandistas ideológicos" y advirtiendo sobre los peligros para la estabilidad del proceso democrático por su accionar guerrillero. ${ }^{17} \mathrm{La}$ disyuntiva quedaba reflejada con elocuencia en la tapa de su número de mayo (Figura 1), donde en medio de la frase escrita en vertical "La opción" se dibujaba los dedos en $\mathrm{V}$ caros al peronismo sobre una bandera argentina frente al puño cerrado sobre un cuadrado rojo que enlazaba con el imaginario de lucha del comunismo. ${ }^{18}$ 
FIGURA 1

Extra, mayo de 1973

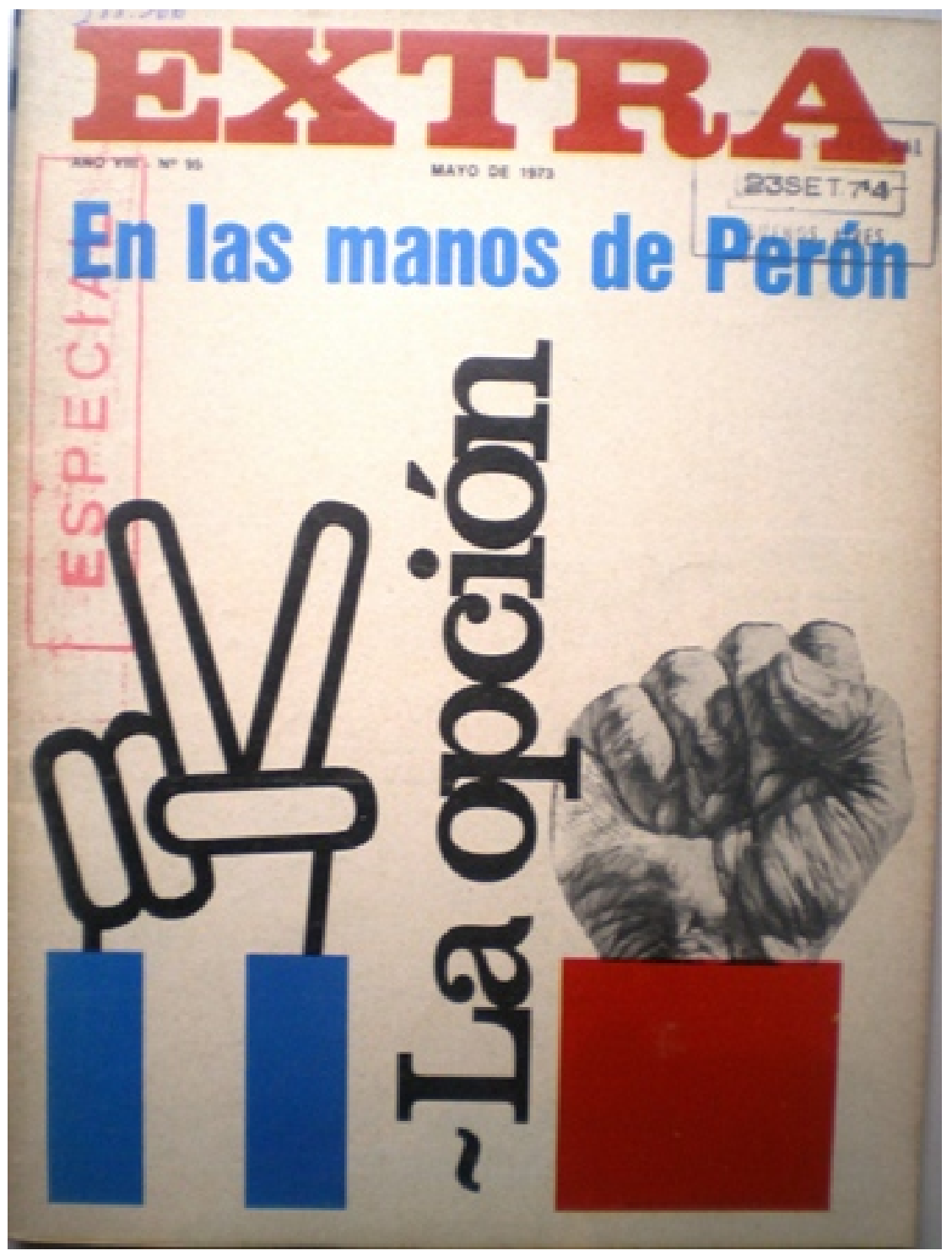

Esta posición inicial de la revista frente a la cuestión de la interna peronista la ubicaba en un lugar enunciativo de "locutor experto" con un discurso predictivo (Rivadaneira Prada, 1986; cit. por Castelli, 1991), que también se atribuyó a sí misma al destacar su capacidad de diagnosticar, predecir y pronosticar qué sucedería respecto de las disputas internas que atravesaban al movimiento. Ese rol autoarrogado se expresó recurrentemente a través de la publicación de notas que hacían referencia a tal capacidad predictiva en las que los vaticinios estuvieron acompañados de imágenes de ediciones anteriores a fin de ofrecer constancias de las predicciones. ${ }^{19}$

La asunción del nuevo gobierno el 25 de mayo de 1973 fue saludada con una inocultable efusión por parte de la revista. ${ }^{20}$ Con pragmatismo, Neustadt se presentó a sí mismo como un consecuente luchador por la concreción de la voluntad popular: "hace 18 años que me imaginaba a las grandes mayorías argentinas asumiendo la conducción de la República. Aspiraba a esa fiesta nítida de los que llegan por la voluntad natural del pueblo". ${ }^{21}$ Incluso, se calificó como un "aliado" del peronismo, al decir que "desde 1955 hasta la fecha, y 
cuando muchos 'eufóricos' de hoy o estaban debajo de las camas o en la vereda de enfrente, expliqué a todos los argentinos la presencia nacional y cristiana, social y humanista del peronismo". ${ }^{22} \mathrm{Y}$ se mostró bastante optimista de las posibilidades de Cámpora: "Tiene los hombres. El radicalismo esta consustanciado con la mayoría del programa expuesto. Los sectores obreros y empresariales, también (...) El plan existe. Ahora es la hora". 23

En este nuevo clima, la revista llegó a justificar la libertad de los presos políticos acaecida por la presión de los militantes el mismo día de la asunción presidencial -antes que se concretara legalmente con la sanción de la ley de amnistía votada por el Parlamento el 26 de mayo- con un discurso afín al nuevo proceso político que se iniciaba: "vale la pena escaparle un poco al formalismo cuando lo que tenemos que establecer para el futuro es que nunca más el drama de la violencia se instale al compás de la marginación de las mayorías, de la desprotección de la industria nacional, de la injusta distribución de la riqueza”. ${ }^{24}$

\section{El CONFLiCto PERonista y LA Violencia política leídos DeSDe EXTRA}

Pero este optimismo inicial resultó efímero. La edición del mes de julio apelaba al temor ante la radicalización del conflicto interno en el peronismo que se había expresado con toda su crudeza en la masacre de Ezeiza. Frente a esta realidad el director apeló al argumento de justificar su posición centrista -y contraria a la radicalización de la izquierda- en el discurso de "autoridad" de Perón, ${ }^{25}$ reafirmando que el líder justicialista era el único que podía definir cuál era la identidad del movimiento en esa coyuntura: “estando Perón en el país, generador de este proceso político, solo a él le corresponde ordenarlo. Porque Perón ordena y quien no está dentro de esos lineamientos... está afuera”. Como ese “ordenamiento” de Perón iba en contra de los intereses del peronismo revolucionario, Extra exponía la contradicción que se hacía cada vez más nítida entre ambos; por ejemplo en su tapa de julio se preguntaba: "¿La verticalidad cuando conviene?" (Figura 2), para luego explayarse:

“Los verticalizados de hoy, ¿discutirán la verticalidad de Perón si no les gusta lo que Perón resuelve? ¿O solo aceptarán la verticalidad si nos conviene? ¿Verticales con el rector Rodolfo Puiggrós [ligado a la Tendencia] y antiverticales con la política económica [por la desaprobación juvenil al Pacto Social y a la elección de José Gelbard como ministro de Economía]?”. 26 
FIGURA 2

Extra, julio de 1973.

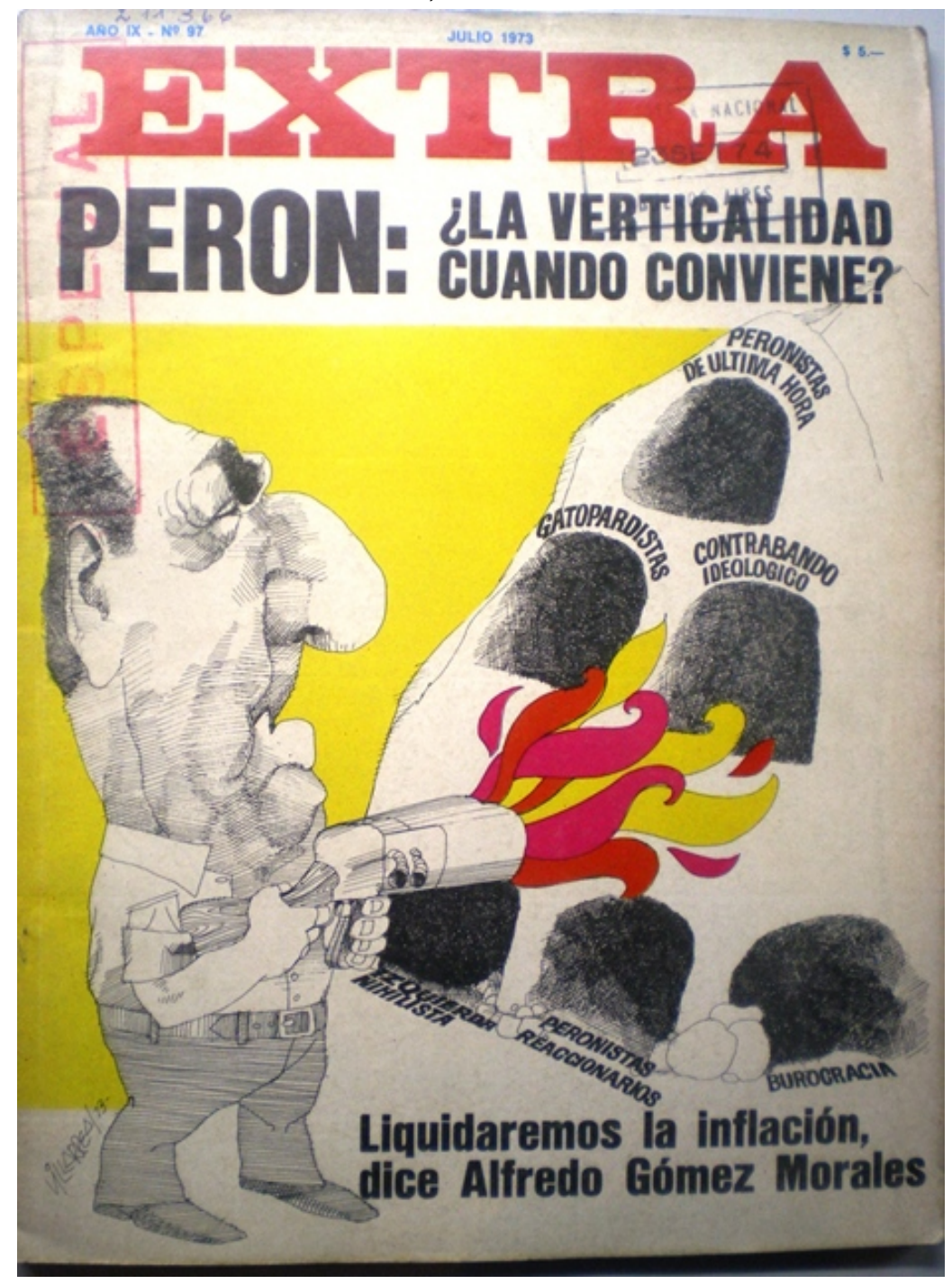

En esta tónica, la revista apeló de modo recurrente a las comparaciones que menospreciaban las intenciones políticas de los sectores juveniles de la izquierda peronista. En principio, escindía entre "la que no tiró balazos en Ezeiza" y quería trabajar en la "reconstrucción nacional" (que en su óptica era la mayoría) y la de los "radicalizados" (“'hijos de“" los tradicionales antiperonistas). ${ }^{27}$ Para más tarde plantear: "Hay que tener cuidado en no mezclar la 'juventud' con la infiltración y a partir de allí iniciar la famosa 'caza de brujas", diferenciando a los "jóvenes activistas" de aquellos que "no salen en los diarios", o los que colaboraban en la "limpieza de la ciudad o en el desagote de los campos", o actuaban en "la ciencia, el arte, la cultura y el trabajo manual" ${ }^{28}$ Y en una argumentación afín con la "derecha" del peronismo, el historiador revisionista y periodista Fernando García Della Costa enfatizaba que los sectores juveniles eran "recién llegados" al movimiento en su nota titulada irónicamente "Palabras para un joven. No es cine: el peronismo no empieza cuando usted llega”. Allí destacaba el desempeño que habían tenido desde 1955 los ahora tildados como "viejos peronistas", considerados como conservadores y liberales por los "jóvenes peronistas", que se presentaban a la vanguardia del proceso político de ese momento en tanto "revolucionarios" y "socialistas" 29. En definitiva, esta perspectiva crítica de la juventud más radicalizada, con diferencias de tonos y de matices, puede ser reconocida como uno de los tópicos discursivos más característicos de la revista durante el período analizado. 
Luego de Ezeiza la relación entre Perón y la Tendencia fue deteriorándose rápidamente, al mismo ritmo que crecía la influencia de López Rega y los sectores sindicales. Inclusive Perón tuvo una serie de encuentros con representantes juveniles y de la Tendencia donde apeló a un abierto destrato y al franco elogio de los sectores de la "derecha" que se le enfrentaban (Larraquy, 2004) ${ }^{30}$ El escenario político, y la interna peronista, se tensó aún más cuando el 25 de septiembre de 1973, a tan solo dos días de la elección presidencial que había consagrado la fórmula Perón-Perón (Juan Domingo Perón-María Estela Martínez de Perón) con casi el 62\% de los votos, era asesinado José Rucci, secretario general de la Confederación General del Trabajo, hombre de confianza del general y principal representante de la "pata sindical" del peronismo (Beraza, 2007). ${ }^{31}$

Frente al asesinato, Extra esgrimió un relato hagiográfico de la figura del dirigente sindical, presentado como un mártir que había dado su vida por el peronismo. De este modo, en permanente contrapunto con los sectores juveniles que disputaban la representación del movimiento, Rucci fue presentado como un hombre menudo, desconfiado, auténtico, generoso, humilde, trabajador, moderado y leal a Perón, que:

"Por supuesto que no había leído a los clásicos, ni tampoco había podido pisar la Universidad. Tal vez por eso no se había ennoviado con el marxismo, en ese romance frívolo que tiene todo 'revolucionario de dúplex' que está a la última moda y que pasa de las villas de emergencias a los salones bien decorados, sin transición y con comodidad”. 32

La revista señaló a un conjunto amplio de responsables indirectos de este homicidio político, dado que según su interpretación "A José Rucci lo mataron entre muchos. De adentro y de afuera" ${ }^{33}$ Aunque señalaba a "los indiferentes, que lo dejaron solo en su lucha no clasista", el texto cargaba las tintas sobre lo que la revista denominaba "los hijos del aburrimiento"; es decir, aquellos "que gritan 'la patria socialista' pero siempre que sea con confort; los que pudieron 'jugar de chicos' mientras Rucci trabajaba 'de todo'”. Si bien ellos no habían disparado, sí formaban parte del "'clima' que asesinó a este hombre”. ${ }^{4}$

El asesinato de Rucci, más allá que no fuera reivindicado abiertamente por Montoneros, fue comprendido por la opinión pública como un mensaje de parte de esa organización revolucionaria hacia Perón y, en concreto, tensó al extremo la relación del líder con la Tendencia. Como consecuencia directa de este hecho, el $1^{\circ}$ de octubre el Consejo Superior del Movimiento Nacional Justicialista hizo llegar una "orden reservada" dirigida a sus delegados en las provincias que ordenaba un estricto acatamiento a las directivas de Perón y una abierta lucha contra las manifestaciones "marxistas" dentro del peronismo, dando inicio a la "depuración ideológica" de las expresiones de izquierda dentro del movimiento. Lejos de toda reserva, el documento fue publicado por la prensa e inició la "caza de brujas" que terminaría expulsando a los sectores revolucionarios del peronismo (Franco, 2012: 51-55; Yofre, 2010: 151-152; el texto completo en Baschetti, 1999: 66-69).

Ante la radicalización del conflicto interno, y la incertidumbre de la situación política nacional, Extra revalidó su postura sobre que Perón era el único con capacidad de resolver los principales conflictos políticos del país. De allí su tapa de octubre, simulando un cheque en blanco extendido al nuevo presidente por los más de siete millones de votantes de las elecciones de septiembre (Figura 3). O el editorial de esa edición, titulado con el elocuente "Perón al poder, con todo el poder", donde expresaba que los votantes lo concebían como el "único político argentino con capacidad de aglutinamiento, de concluir con los estertores de la violencia, de organizar el país y de sacarnos el fantasma de la guerra civil de encima”. ${ }^{35}$ Luego de la asunción presidencial del 12 de octubre de 1973, la revista ratificó ese diagnóstico según el cual lo que "ilusionaba" de Perón era su "capacidad de poner orden, quitarnos la anarquía de encima y saber lo qué (sic) hay que hacer con el Estado" ${ }^{36}$ 
FIGURA 3

Extra, octubre de 1973

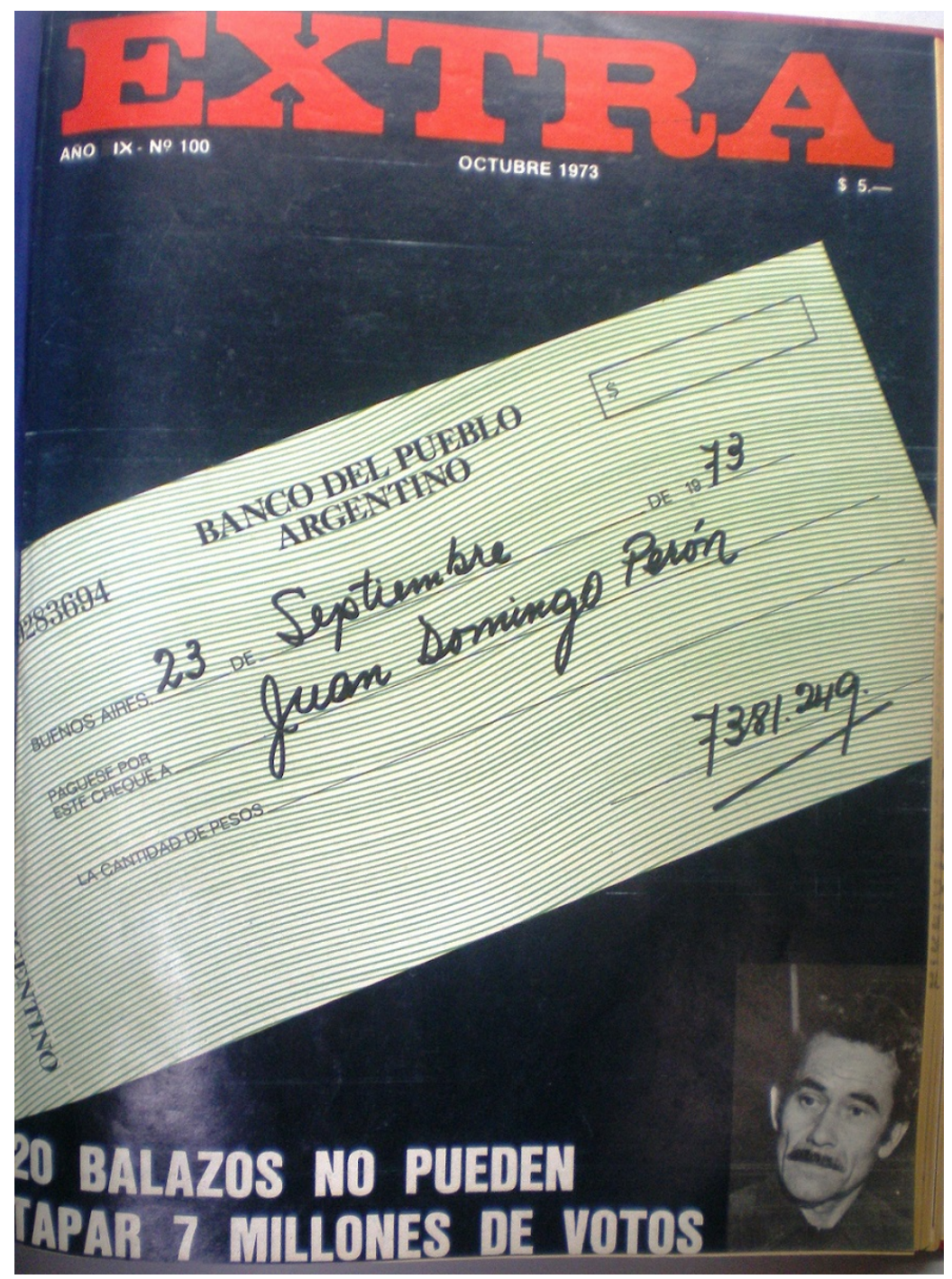

Hacia noviembre de 1973, para Extra era claro que el peronismo estaba viviendo su propia " 'guerra civil en miniatura" ” en la que solo el "protagonismo de Perón” impedía "la anarquía”. ${ }^{37}$ En un editorial exclusivamente dedicado al tenor y las consecuencias negativas del conflicto, Neustadt relataba con crudeza el nivel de violencia que estaba adoptando el conflicto, el "odio" que lo recorría, y describía que la disputa era tan "impresionante" que cubría todo el escenario político, siendo el peronismo "oficialismo y oposición" al mismo tiempo. Para el director, Perón planteaba un país de "centro", ni de derecha ni de izquierda, y debía lidiar con los militantes de ambos bandos. Según tal interpretación, tanto los "'útopicos apresurados" como los "abúlicos retardatarios" deberían dejar de batallar y reconocer el protagonismo de Perón, ya que de otro modo los "adversarios" aprovecharían el fracaso para retrotraer al país a sus "frustraciones anteriores". El problema no eran las discrepancias, sino el modo en que se desarrollaban, donde se prefería "imponer" más que persuadir y donde imperaba la lógica de la "traición" para el que pensaba diferente (el ejemplo contrario que mencionaba era nuevamente el del radicalismo, donde el que perdía la interna debía admitir el pensamiento del otro). Para el periodista, ambos bandos eran, a su manera, peronistas, debían aceptar que habían trabajado para el retorno de Perón al poder, que su "exagerado purismo" estaba " "vaciando" " de poder al líder y que el “desgarro" peronista favorecía a los que esperaban o deseaban el fracaso de Perón. ${ }^{38}$ 
Si bien el director trataba de mantener cierto equilibrio, era evidente que la responsabilidad primaria del conflicto estaba puesta en el desafío planteado por el peronismo revolucionario. Como se ha analizado, ya desde la propia nominación estos sectores eran estigmatizados al mencionarlos como "los ultras", "los intrusos", "los contrabandistas ideológicos", la "izquierda disfrazada de peronista", "los profetas de la comodidad que trabajan de izquierdistas", términos que estaban a tono con la noción de "infiltración" invocada desde el programa de "depuración ideológica". Paralelamente, si bien Extra no exhibió un apoyo editorial explícito al ala "derecha" del peronismo, publicó múltiples solicitadas de sindicatos peronistas y notas especiales referidas al tema gremial -de claro cariz propagandístico- que mostraban su sintonía con el sector. ${ }^{39}$

Otro aspecto destacado en el discurso de la publicación, que se articulaba con su desaprobación del extremismo de izquierda, fue la exhortación a que las organizaciones político-armadas depusieran su accionar frente al cambio de escenario político que había implicado el fin de la dictadura:

“Antes tenían de excusa al gobierno militar. Ahora sus metralletas disparan contra el frente interno en nombre de un jacobinismo que nadie les pidió representar. Mantienen el ritmo de la etapa de guerra y no sirven para la paz. Cuando se ordena el cese del fuego y no existe enemigo enfrente, vuelven las armas contra su propio espejo y en un puritanismo mesiánico matan a José Rucci, por ejemplo" 40

Su diatriba se volvió aún más incendiaria luego que el ERP atacara la guarnición militar de Azul en la provincia de Buenos Aires, el 19 de enero de 1974, en una acción que tuvo un grave impacto político. ${ }^{41}$ Con estridencia, el director advirtió que: "Secuestrar empresarios, asesinarlos; atacar la política económica que él (Perón) respalda; raptar militares, desacreditar la conducción sindical, es desobedecerle. Es quemar la alternativa de la soberanía popular nacida en función de Perón. Es ser ácratas. (...) Es, en última instancia, la antesala de la aventura mayor: asesinar a Perón. Después de lo visto ¿̇se puede dudar que esa idea anida entre estos enfermos irremediables?”. ${ }^{42}$ Desde su punto de vista, lo ocurrido en Azul tendría que ser "la tumba de la guerrilla" y "con la ley en la mano" Perón y su gobierno debían ser "implacables" ${ }^{43}$

Aunque durante el período analizado la revista esgrimió una manifiesta condena a la muerte como forma de hacer política y, en tal sentido, exigió una "gran convocatoria nacional de los líderes políticos, con Perón al frente (...) para enfrentar al enemigo común: la violencia, ${ }^{44}$ también es posible reconocer un tratamiento diferencial de la muerte en función de la adscripción política de la víctima en un ala o en otra del movimiento peronista. En tal sentido, los asesinatos de sindicalistas adquirieron un lugar de preeminencia, en el marco de una amplia tematización del tema gremial en las notas y, sobre todo, en el considerable número de avisos y solicitadas pagas por los gremios que la revista publicó durante todo el período. ${ }^{45}$

A inicios de 1974 el distanciamiento entre la Tendencia y Perón sumó otro episodio relevante, cuando los ocho diputados ligados a la izquierda peronista renunciaron a sus bancas al negarse a aprobar la reforma al Código Penal que endurecía las penas para las acciones guerrilleras y era impulsada por el presidente. ${ }^{46} \mathrm{La}$ perspectiva sobre que la Tendencia se estaba convirtiendo en un grupo exógeno al peronismo fue puesta en evidencia por Extra, en su edición de febrero de 1974, al reproducir un documento crítico de Montoneros hacia el gobierno. Al constatar que ese duro juicio era finalizado con el clásico "Perón o muerte", expresaba:

“Pero resulta que el gobierno que no hace la patria que quiere 'Montoneros' está presidido por Juan Perón. ¿Entonces? ¿Hasta dónde sigue la sociedad nacida en las (sic) hora del ostracismo? ¿O se rompe ya? ¿O para 'Montoneros', como lo dicen en voz baja, 'Perón es un reformista y no un revolucionario'? Si fuera así, ¿no es más auténtico desprenderse del papá, liberarse de usar su nombre y de admitirlo como jefe y buscar autenticidad lejos de la camiseta peronista?”. 47 
Pese a la aprobación de Extra a la "depuración ideológica", la revista alertó sobre las "formas" que estaba llevando su "instrumentación”. Ante el golpe policial con apoyo de la derecha peronista -y del propio Perón- que destituyó al gobernador cordobés Ricardo Obregón Cano en febrero de 1974 (Servetto, 2010), la publicación indicó la "ineptitud" con que se había realizado la "depuración", tanto porque no se podía premiar la "subversión" "venga del lugar que viniere", como el rol principal que había tenido que ocupar Perón en la destitución. En resumen, no se cuestionaba "que Perón 'purgue' a su Movimiento" sino que los "instrumentistas" carecieran de la "habilidad" y la "prolijidad", transformando un "caso político" [el de Córdoba] en una "pesadilla”, poniendo en riesgo así "todo el sistema institucional" ${ }^{48}$

La ruptura de Perón con la Juventud peronista el $1^{\circ}$ de mayo, luego que Perón los llamará "imberbes" y "estúpidos” y éstos se retiraran de la Plaza, dejó más dudas que certezas en la revista: ¿era realmente el fin de lo que denominaba como una "delicada relación”?, ${ }^{49}$ ¿los jóvenes se quedarían dentro del movimiento o se irían al "socialismo 'de verdad'”, ¿insistirían con la idea de un Perón "cercado"?, ¿decidirían seguir siendo representados por una cúpula que los había llevado al "error táctico" de enfrentarse con Perón? Por su parte, lo de Perón, ¿̇era un "tirón de orejas" o una "declaración de guerra" ? ${ }^{50}$ Estos interrogantes quedaron abiertos ante la posterior muerte de Perón acontecida el $1^{\circ}$ de julio de 1974.

Frente a este nuevo escenario, Extra albergó cierta esperanza en la continuidad del camino de la "unión nacional" trazado en vida por el presidente. Para ello, el "deber" de los argentinos en la hora era "seguir unidos detrás de quien le ha sucedido" -es decir, Isabel Perón- y colaborar con la "superación de los intereses sectoriales". ${ }^{51}$ En torno al peronismo propiamente dicho, en un breve recuadro aducía con cierto optimismo que pese a la "gran preocupación" que existía en su conducción por el fallecimiento del líder, debía evaluarse positivamente que Perón no había identificado su vida "con la del Movimiento" y depositaba la esperanza en que sus dirigentes en tanto "hombres de lucidez" pudieran dar cuenta del desafío de concretar el deseo de su máximo dirigente. ${ }^{52}$

\section{Conclusiones}

La interpretación ofrecida por Extra del retorno del peronismo al poder y del conflicto suscitado entre sus filas no puede ser explicada sin considerar dos aspectos fundamentales de su línea editorial: el particular estilo periodístico y el lugar de enunciación de la revista fuertemente articulados en torno de la figura de Bernardo Neustadt, su director.

En torno al primero, Extra hizo gala de un estilo periodístico directo, polémico, confrontativo y provocador, elaborado a partir del uso recurrente de preguntas retóricas, metáforas y comparaciones simples, letras capitales y negritas y de una abundante adjetivación. A partir de este estilo, la revista interpelaba a sus lectores elaborando un lugar de enunciación experto, autodefinido como sin banderías político-partidarias, "neutral" ante los conflictos políticos sobre los que opinaba y consustanciado con los intereses de "la gente".

La apelación a la ideología de centro constituyó la clave interpretativa fundamental para decodificar los conflictos en el interior del peronismo. El destinatario principal de la prédica de Extra fueron justamente aquellos definidos como "los moderados", los cuales funcionaron como contrapunto discursivo de los llamados "ultras". Según tal argumentación, era necesaria una nueva clase dirigente formada, capaz de superar los extremos representados por la derecha y la izquierda y de terminar con el ciclo recurrente de la fallida unidad nacional. De todas formas, subyacía a esa prédica centrista una clara animadversión hacia las pretensiones revolucionarias de la izquierda peronista, cuyas acciones fueron estigmatizadas y denominadas bajo una retórica cada vez más excluyente, lo que al menos ponía bajo interrogante la verdadera convicción de ese llamado a la "moderación". A tono con ello, fueron ponderadas positivamente las posiciones del sindicalismo peronista y de los "peronistas históricos", quienes tuvieron un lugar privilegiado en su superficie redaccional. 
La figura de Perón fue elogiada y legitimada por su simultánea intención de alejar a la clase obrera del marxismo y a las clases medias del liberalismo y, por lo tanto, de representar los intereses y anhelos del sector moderado o centrista de la opinión pública nacional. Su palabra y acción eran las únicas que podían ordenar las disputas de su movimiento y por tanto debían ser acatadas sin cuestionamientos. Aquellos sectores que no lo hicieran -particulamente, la izquierda revolucionaria-, o quisieran "infiltrarse" para concretar el "contrabando ideológico", debían ser excluidos.

Con la muerte de Perón, pese al inicial deseo que Isabel mantuviera el camino de la "unidad nacional", este pretendido centrismo político que anhelaba superar las históricas antinomias nacionales se irá diluyendo en un escenario político que será colmado definitivamente por las opciones extremas, en el marco de un vertiginoso proceso de espiralización de la violencia política.

\section{REFERENCIAS}

Acha, O. (2004). Sociedad civil y sociedad política durante el primer peronismo. Desarrollo Económico, 174, 199-230. Baschetti, R. (comp.) (1999). De la ruptura al golpe. Documentos 1973-1976, Vol. II. Buenos Aires: de la campana.

Becerra, M. (2010). Las noticias van al mercado: etapas de intermediación de lo público en la historia de los medios de la Argentina. En G. Lugones \& J. Flores (comps.) Intérpretes e interpretaciones de la Argentina en el bicentenario (pp. 139-165). Bernal: UNQUI.

Beraza, L. F. (2007). José Ignacio Rucci. Buenos Aires: Vergara.

Besoky, J. L. (2016) La derecha peronista. Prácticas politicas y representaciones (1943-1976). Tesis para optar por el grado de Doctor en Ciencias Sociales. Universidad Nacional de La Plata.

Bonasso, M. (1997). El presidente que no fue. Los archivos ocultos del peronismo. Buenos Aires: Planeta.

Bosoer, F. (2013). Detrás de Perón. Historia y leyenda del almirante Teisaire. Buenos Aires: Capital Intelectual.

Bufano, S. y Teixido, L. (2015). Perón y la Triple A. Las 20 advertencias a Montoneros. Buenos Aires: Sudamericana.

Carman, F. (2015). Elpoder de la palabra escrita. Revistas y periódicos argentinos (1955-1976). Buenos Aires: Ediciones de la Biblioteca Nacional.

Castelli, E. (1991). Manual de periodismo. Buenos Aires: Plus Ultra.

Csipka, J. P. (2013). Los 49 dias de Cámpora. Crónica de una primavera rota. Buenos Aires: Sudamericana.

De Riz, L. (2000). La política en suspenso (1966-1976). Buenos Aires: Paidós.

Fernández Díaz, J. (2018). El hombre que se inventó a sí mismo. Planeta: Buenos Aires [Ed. Orig., 1993].

Ferreyra, S. (2018). El peronismo denunciado. Antiperonismo, corrupción y comisiones investigadoras durante el golpe de 1955. Buenos Aires-Mar del Plata: Grupo Editor Universitario-Editorial de la Universidad Nacional de Mar del Plata.

Franco, M. (2012). Un enemigo para la nación: orden interno, violenciay "subversión", 1973-1976. Buenos Aires: Fondo de Cultura Econo\#mica.

Getino, O. (1995). Las industrias culturales en la Argentina: Dimensión económica y politicas públicas. Buenos Aires: Colihue.

Maceyra, H. (1983). Cámpora/Perón/Isabel. Buenos Aires: CEAL.

Manzano, V. (2017). La era de la juventud en Argentina. Cultura, politica y sexualidad desde Perón a Videla. Buenos Aires: FCE.

Merele, H. (2017). La depuración ideológica del peronismo en General Sarmiento, 1973-1974: Una aproximación al proceso represivo durante los años setenta constitucionales a partir del caso de Antonio Tito Deleroni. La PlataLos Polvorines-Misiones: Universidad Nacional de La Plata-Universidad Nacional de General SarmientoUniversidad Nacional de Misiones. 
Neustadt, B. (1995). No me dejen solo. Buenos Aires: Planeta.

Larraquy, M. (2004). López Rega. Buenos Aires: Sudamericana.

Ollier, M. M. (2005). Golpe o revolución. La violencia legitimada, Argentina 1966/1973. Caseros: Eduntref.

Perón, J. (1974a).Juan D. Perón 1973-1974. Sus discursos, mensajes y conferencias completos. Volumen I. Buenos Aires: Editorial de la Reconstrucción.

Perón, J. (1974b). Juan D. Perón 1973-1974. Sus discursos, mensajes y conferencias completos. Volumen II. Buenos Aires: Editorial de la Reconstrucción.

Pozzoni, M. (2017) Leales. De la Tendencia Revolucionaria a la Juventud Peronista Lealtad. Buenos Aires: Imago Mundi.

Reato, C. (2017). Operación Traviata: ¿Quién mató a Rucci? La verdadera historia. Buenos Aires: Sudamericana.

Servetto, A. (2010). 73/76: el gobierno peronista contra las "provincias montoneras". Buenos Aires: Siglo XXI.

Sigal, S., \& Vero\#n, E. (2003). Pero\#n o muerte: los fundamentos discursivos del feno\#meno peronista. Buenos Aires: EUDEBA.

Svampa, M. (2007). El populismo imposible y sus actores. En Nueva Historia Argentina, 1955-1976 (pp. 381-438). Buenos Aires: Sudamericana [Edición original, 2003].

Taroncher, M.A. (2009). La caída de Illia. La trama oculta del poder mediático. Buenos Aires: Javier Vergara Editor.

Tcach, C. (2002). Heterodoxo diccionario de consignas orales. En C. Tcach (comp.), La politica en consignas. Memoria de los setenta (pp. 13-78). Rosario: Homo Sapiens.

Tortti, M. C. (1999). Protesta social y 'nueva izquierda' en la Argentina del Gran Acuerdo Nacional. En: A. Pucciarelli (ed.). La primacía de la politica. Lanusse, Perón y la Nueva Izquierda en tiempos del GAN (pp. 205-231). Buenos Aires: EUDEBA.

van Dijk, Teun, A. (1990). La noticia como discurso. Comprensión, estructura y producción de la información. Buenos Aires: Paidós.

Verbitsky, H. (1998). Ezeiza. Buenos Aires: Planeta. [Edición original, 1986].

Verón, E. (1985). El análisis del contrato de lectura, un nuevo método para los estudios del posicionamiento de los soportes de los media. En: Les medias: Experiencias, recherches, aplications. París: IREP.

Vommaro, G., y Baldoni, M. (2012). Bernardo y Mariano: las transformaciones del periodismo político en Argentina de los años ochenta a los años noventa. Mediálogos, 2, 59-81.

Yofre, J. B. (2010). El escarmiento. La ofensiva de Perón contra Cámpora y los Montoneros, 1973-1974. Buenos Aires: Sudamericana.

\section{Fuentes}

Revista Extra, N93-109, años VIII-X, 1973-1974

\section{Notas}

1 Este artículo se enmarca dentro de los proyectos de investigación PICT- 2016-0063 "Las revistas políticas argentinas en la encrucijada nacional: del peronismo al golpe (1973-1976)", financiado por la Agencia Nacional de Promoción Científica y Tecnológica, y el proyecto UBACyT 20020170200067BA "La prensa política argentina, de Cámpora a Videla (1973-1976)" dirigidos por el segundo autor. Los autores desean agradecer las constructivas sugerencias de los evaluadores de este artículo. 
2 Entre 1958 y 1974, la Argentina alcanzó los mayores índices de producción en cuanto a títulos y a ejemplares de diarios de toda su historia. Estas cifras sufrieron una abrupta modificación a partir de 1975, cuando producto de la crisis económica se suscitó una brusca caída, cercana al 50\%. En este sentido, el período analizado constituye un momento bisagra en la evolución de las industrias culturales argentinas, particularmente de la prensa gráfica, que a partir de 1975, junto con una abrupta depresión en las ventas sufrió transformaciones de largo plazo, como la concentración económica y territorial de los productores de este tipo de bienes con su impacto directo en la pérdida de diversidad en la oferta (Getino, 1995; Becerra, 2010).

3 Teisaire fue vicepresidente de la Nación entre el 7 de mayo de 1954 y el 16 de septiembre de 1955, durante la segunda presidencia del general Juan Domingo Perón.

4 Durante el segundo gobierno peronista, la Secretaría de Asuntos Políticos había llegado a la conclusión que la adhesión de las asociaciones civiles al peronismo era aún parcial, por lo que a partir de 1954 emprendió la tarea de cooptación del asociacionismo vecinal y el fomentismo (Acha, 2004). Como principal responsable de relaciones con las "Organizaciones del Pueblo”, Neustadt coordinó y monitoreó estas operaciones de cooptación y ocupación de lo asociativo.

5 A los pocos días del golpe de Estado, el gobierno militar creó por decreto la llamada Comisión Nacional de Investigaciones, destinada a investigar las supuestas irregularidades y delitos cometidos durante el gobierno depuesto (un estudio detallado de esta institución, su funcionamiento y el alcance de sus tareas puede encontrarse en Ferreyra, 2018). En este marco, Neustadt estuvo detenido varios días en la Penitenciaría Nacional y tuvo que brindar testimonio en la Comisión No 8, especialmente creada para juzgar a la figura del ex vicepresidente Teisaire. Aunque sospechado de enriquecimiento ilícito por la adquisición espuria de un periódico, la comisión sólo concretó la acusación del periodista por falso testimonio.

6 El programa político Tiempo Nuevo empezó a ser emitido en 1969 y durante la década de los ochenta y principios de los noventa se convirtió en un espacio de referencia ineludible para los dirigentes políticos (Vommaro y Baldoni, 2012).

7 Bernardo Neustadt, “'Ser de centro' será 'in' ”, Extra, noviembre de 1973, p. 8. Inclusive Extra se propuso asumir un papel destacado en la construcción de una opción de centro para lo que en febrero de 1974 lanzó la encuesta “¿Por qué no existe una ideología de centro?”, en la cual reunió a diferentes figuras del campo político, sindical, artístico e intelectual de la época para preguntarles sobre la "definición ideológica para estas voluntades mayoritarias que ya archivaron a Adam Smith y arrinconaron a Marx". Aunque las respuestas recibidas poco parecen acordar con la propuesta elaborada por la publicación, y en su lugar advierten sobre el carácter inestable, poco preciso e incluso reaccionario de tal posición de centro, el reportaje concluyó que las elecciones que meses antes habían consagrado a Perón por tercera vez presidente de la Nación expresaban con claridad la voluntad de ese "hombre razonable" crítico de cualquier extremismo. Extra, “Argentina 74, ¿Por qué no existe una ideología de centro?, febrero de 1974, p. 18.

8 Una coalición de partidos liderada por el peronismo que se completaba con el desarrollismo y pequeños sectores desprendidos del socialismo, el radicalismo y los conservadores populares.

9 Como explica Pozzoni, el surgimiento y la evolución de la llamada Tendencia Revolucionaria del peronismo puede ser vista como un emergente de la radicalización política que caracterizó la etapa transcurrida entre fines de la década de 1960 y principios de los años '70. Hacia 1973, la Tendencia Revolucionaria estaba compuesta por la organización política-armada Montoneros y sus agrupaciones de superficie: la Juventud Peronista Regionales (JPR), el Movimiento Villero Peronista (MVP), la Juventud Universitaria Peronista (JUP), la Juventud Trabajadora Peronista (JTP), la Unión de Estudiantes Secundarios (UES) y el Movimiento de Inquilinos Peronistas (MIP), junto con otras agrupaciones autónomas como las Fuerzas Armadas Revolucionarias, las Fuerzas Armadas Peronistas 17 de Octubre (FAP-17) y el Peronismo de Base (Pozzoni, 2017).

10 Bernardo Neustadt, “¿Quiere Ud. Imaginarse una elección sin el peronismo”, Extra, marzo de 1973, p. 15. El director lo reconocía con total realismo político en abril de 1973, luego de la elección: "Una señora de origen francés me decía que estaba contenta el domingo porque el triunfo del gaullismo se oponía a la izquierda y en cambio temblaba por la victoria peronista. ¿Pero no se da cuenta que técnicamente es la misma opción? ¿Qué ningún extremismo ni de derecha ni de izquierda puede existir en la Argentina mientras no empujemos a la masa que vota por el justicialismo a la desesperación, como sería entregarle el poder o hacerle un fraude técnico?”. Bernardo Neustadt, “iSeamos adultos!: Cámpora es el presidente", Extra, abril de 1973, p. 7.

11 Extra, "La tormenta de los generales", marzo de 1973, p. 8. Extra fue explícita en su oposición a las tendencias proscriptivas dentro de las Fuerzas Armadas; inclusive publicó una doble página bajo el titular "Sin comentarios" donde se contrastaban los titulares de diarios donde los militares se comprometían a la "no proscripción", la "pacificación" y la "unión nacional" con el titular del diario La Nación del 7 de febrero de 1973 donde se informaba que por decisión de la Junta gobernante Perón no podría volver al país hasta que asumiera el nuevo gobierno electo. El montaje era acompañado por un gran signo de interrogante que enfatizaba, con indudable ironía, la preocupación de la revista frente a esta situación (véase también sobre el tema Clarín, "Perón no podrá ingresar al país antes de los comicios", 7 de febrero de 1973, p. 19). 
12 Hacía mención a la "acción psicológica” de esas “usinas" por un informe que había circulado por manos militares en el que se informaba que en el hipotético gobierno peronista se encumbrarían altas figuras de la juventud más "dura” del peronismo, habría una vuelta al "culto a la personalidad de Perón” -como en sus primeros gobiernos- y se impondría el "revanchismo" al derogar toda la legislación represiva y la propia Constitución, tras lo cual se pondría en vigencia la de cuño peronista de 1949. Extra, "Eso llamado acción psicológica”, marzo de 1973, p. 11.

13 Bernardo Neustadt, “Seamos adultos!: Campora es el presidente”, Extra, abril de 1973, p. 7.

14 Extra, "Sabemos quién ganó; falta saber quién gobernará...”, abril de 1973, p. 3.

15 Extra, "El 'soldado' de Perón”, mayo de 1973, p. 3.

16 Bernardo Neustadt, "En las manos de Perón”, Extra, mayo de 1973, p. 15.

17 El ejemplo opuesto donde sí se verificaba el "trasvasamiento generacional” era el radicalismo, "el de Ricardo Balbín a Raúl Alfonsín o a Fernando de la Rúa” donde se seguían las “corrientes naturales” y no se cambiaba el "sello ideológico" como querían los “intrusos" del peronismo. Además, el Justicialismo era "nacional”, mientras que el "socialismo” tenía “connotaciones extranjerizantes”. Extra, “¿Trasvasamiento generacional o ideológico?”, mayo de 1973, p. 75.

18 Este mensaje era reforzado en el interior de la edición en un recuadro donde se presentaba la posición del trotskista Ejército Revolucionario del Pueblo (ERP) en 1971 que calificaba a Perón como defensor de los intereses burgueses y figura "contrarevolucionaria". El recuadro cerraba con un lacónico: "Usted juzque".

19 “Lo pronosticamos", Extra, junio de 1973, p. 6; "Esto lo dijimos hace un año”, Extra, octubre de 1973, p. 64; “¿Quién tenía razón?”, Extra, febrero de 1974, p. 11; “Pronósticos desde el ayer”, Extra, junio de 1974, p. 12. Con el mismo tono, en marzo de 1974, el director aseguraba: "No oculto mi vanidad: muchas de las reflexiones que durante estos dos últimos años volqué apasionadamente, hoy dejan de ser fantasmas y asumen su corporización. Hablé entonces (1971) del 'contrabando ideológico', 'de los infiltrados', de los 'revolucionarios de dúplex', de 'los hijos del aburrimiento', de los que querían transformar a Perón en el abanderado de 'la patria socialista'. De los que pretenden rebautizar al justicialismo con el concepto de socialismo nacional". Bernardo Neustadt, “Se ruega dirigirse a Perón”, Extra, marzo de 1974, p. 17.

20 Según recuerda Bonasso (1997: 409), Neustadt, invitado a la televisión por el popular personaje "La Chona”, había "confesado" su voto por la dupla Cámpora-Vicente Solano Lima.

21 Y agregaba, autoexcluyéndose del antiperonismo: "Durante 18 años explicamos al antiperonismo que el peronismo existía. Combatimos arbitrariedades, crímenes y mortificaciones”. Bernardo Neustadt, “iImposible callar!”, Extra, p. 15.

22 Bernardo Neustadt, “iTodo quedó claro!”, Extra, abril de 1973, p. 16. La nota reproducía una carta que Neustadt le había hecho llegar al director del diario peronista Mayoría y que había sido publicada por ese periódico el 10 de marzo de 1973.

23 Bernardo Neustadt, “iImposible callar!”, Extra, junio 1973, p. 15. La mención al radicalismo puede entenderse por la aprobación de la revista al acercamiento que se había dado entre Perón y el líder radical Balbín.

24 Bernardo Neustadt, “iImposible callar!”, Extra, junio 1973, p. 15.

25 Incluso Neustadt se arrogó cierta clarividencia política en una columna titulada “Ahora lo dijo Perón”, donde Extra legitimaba su postura al intercalar las opiniones de Neustadt con las declaraciones de Perón del 21 de junio, un día después de la masacre de Ezeiza, donde en la misma sintonía el líder expresó su desaprobación hacia los sectores revolucionarios del movimiento. Extra, “Ahora lo dijo Perón”, julio de 1973, p. 13.

26 Bernardo Neustadt, "Perón, y punto", Extra, julio de 1973, p. 19.

27 Bernardo Neustadt, "Perón, y punto", Extra, julio de 1973, p. 18.

28 Bernardo Neustadt, “Ser de centro' será 'in "”, Extra, noviembre de 1973, p. 8. En esa misma orientación, en su edición de julio de 1973 había publicado la opinión de varios jóvenes no identificados con una ideología de izquierda sobre el primer mes de gobierno y titulaba “También son jóvenes", para destacar el contraste (Extra, julio de 1973; pp. 40-42).

29 El artículo había sido publicado previamente en el periódico peronista y oficialista Mayoría. Fernando García Della Costa, "Palabras para un joven. No es cine: el peronismo no empieza cuando usted llega", Extra, julio de 1973, p. 125.

30 Luego de Ezeiza, la Tendencia planteó lo que se conoció como la “teoría del cerco”, por la cual Perón estaba siendo engañado por personajes de su entorno, principalmente su secretario privado López Rega, que le impedían tener un contacto directo con el pueblo. Por ello sus representantes debían tener un contacto "sin intermediarios" con el líder, para que este supiera de primera mano qué era lo que estaba ocurriendo y por lo tanto sus juicios estuvieran fundados en la realidad y no en el engaño (Sigal y Verón, 2003).

31 El asesinato fue realizado por Montoneros, aunque no reivindicado públicamente, lo cual dejó abierta en la opinión pública diversas conjeturas sobre sus responsables (Reato, 2017)

32 Extra, ¡Pobre Rucci!, octubre de 1973, p. 1.

33 Ibíd.

34 Ibíd.

35 Bernardo Neustadt, "Perón al poder, con todo el poder", Extra, octubre de 1973, p. 14.

36 Extra, "O juremos con gloria vivir", noviembre de 1973, p. 5. El rol insustituible que le cabía al líder en esta coyuntura 
volvía de máxima relevancia considerar la salud precaria del general a sus 78 años, como era públicamente conocido. Según Neustadt "cuanto más viva Perón, más segura estará la democracia efectiva”, pero ante la inevitable pregunta sobre un sucesor entendía que su gran legado sería dejar "instituciones en vez de algún Delfín”. Bernardo Neustadt, "La noche que 'no murió Perón”, Extra, diciembre de 1973 (s/p).

37 Extra, "Para un peronista no hay nada mejor que... ¿qué?”, noviembre de 1973, p. 14.

38 Ibid.

39 Los gremios metalúrgico, textil, automotriz, del seguro, gastronómico y de la construcción fueron los que, durante 1973 y 1974, recibieron el tratamiento más favorable en la publicación. En particular, se destaca el caso de la Unión Obrera Metalúrgica (UOM), liderada por el poderoso Lorenzo Miguel, sindicato que fue uno de los principales anunciadores de esta etapa. Vale consignar a modo de ejemplo de esta relación el aviso de página completa, publicado en octubre de 1973 en el contexto del tratamiento del caso Rucci, en el que podía leerse: "La Unión Obrera Metalúrgica deja expresa constancia de su reconocimiento a la revista EXTRA al cumplir sus primeras 100 ediciones por haber pintado la realidad sindical argentina sin ninguna adulteración. Los trabajadores se vieron interpretados plenamente en su conducta nacional y cristiana sin exclusivismos. Así se honra a la libertad de prensa y se cumple la misión de un medio de comunicación independiente y sincero". Extra, octubre 1973, p. 46. O la nota de cariz propagandístico: "Metalúrgicos: abanderados de una responsabilidad”, Extra, marzo de 1974, pp. 37-40. También dirigentes gremiales como Miguel Gazzera o Cesáreo Melgarejo solían colaborar como columnistas invitados.

40 Extra, "Perón al poder con todo el poder", octubre de 1973, p. 15.

41 Es probable que los hechos de Azul hayan sido un punto de inflexión en cierta tolerancia que Perón había demostrado hasta ese momento con la violencia guerrillera. A corto plazo, inició un nuevo clima político donde los discursos de amplios sectores de la sociedad civil se mancomunaron para denunciar a la "subversión" (Franco, 2012: 75), bajo una radicalidad discursiva expresada por el propio Perón, quien poco después del asalto, por cadena nacional y vestido de uniforme militar, afirmó que había que "aniquilar cuanto antes este terrorismo criminal” (Franco, 2012: 70). Repercutió también en la "depuración” interna del peronismo: el gobernador de la provincia de Buenos Aires cercano a la Tendencia, Oscar Bidegain, fue presionado para renunciar tras la acusación de Perón por la "desaprensión e incapacidad" y la "tolerancia culposa" de las autoridades de esa provincia que según el presidente habían permitido el ataque (Perón, 1974b: 32).

42 Bernardo Neustadt, "La paciencia de Perón”, Extra, febrero de 1974, p. 14. Recuérdese que el día de la asunción de su tercera presidencia Perón dio un discurso desde el balcón de la casa de gobierno resguardado por un vidrio blindado.

43 Frente al desafío guerrillero, Extra realizó una encuesta-sondeo (formato habitualmente utilizado por la revista) a un conjunto de políticos con la pregunta “¿Cómo terminar con la guerrilla?”. Extra, “Cómo terminar con la guerrilla?”, febrero de 1974, pp. 42-43.

44 Extra, ¡Muera la muerte!, abril de 1974, p. 5. Otras expresiones contra la violencia política y los extremismos pueden leerse en: “Asesinatos, secuestros, ¿un estilo de vida? ¿Qué hacemos?” (entrevista a Fernando de la Rúa), Extra, abril de 1974, p. 21; Bernardo Neustadt, “La 'nueva minoría”, Extra, junio de 1974, p. 15.

45 A su vez, frente a ciertos atentados se sembraron sospechas sobre el sector revolucionario. Ante el asesinato del Padre Carlos Mugica en mayo de 1974, cuya figura estaba vinculada a los sectores revolucionarios del peronismo, Extra ofreció indicios sobre que había sido ese mismo sector el responsable. Para ello publicó el fragmento de una nota de Mugica aparecida en marzo en el diario Mayoría donde criticaba cierta actitud de los sectores juveniles, la opinión del dirigente sindical Cesáreo Melgarejo (“¿Quién fue?”) que iba en el mismo sentido y una superposición de titulares sobre el asesinato de Aramburu y el de Mugica ("De Aramburu a Mugica”), entrelazando ambos acontecimientos. En tanto el primero había sido autoría de Montoneros, y el de Mugica no había sido adjudicado por grupo alguno, la relación se desprendía implícitamente. La nota de Neustadt "'Pena de muerte privada" iba en un sentido similar (Extra, junio de 1974, p. 20) (como se sabrá posteriormente, el asesinato fue responsabilidad de la Alianza Anticomunista Argentina, más conocida como "Triple A", organización paramilitar de derecha creada en las sombras por López Rega -Larraquy, 2004-). La misma argumentación fue presentada luego del asesinato del sindicalista Rogelio Coria, ocurrido el 22 de marzo de 1974, y frente al atentado sufrido por el Secretario General del Partido Justicialista Juan Manuel Abal Medina un día después. Para este último caso, para apuntar a la Tendencia se mencionaba que Abal Medina se había apartado de las posiciones “radicalizadas” y no compartía la forma de actuar de Montoneros. Extra, “iMuera la muerte!”, abril de 1974 , p. 5.

46 El 22 de enero de 1974 los diputados se reunieron con Perón para plantearles sus objeciones. El general los sorprendió con las cámaras de televisión, flanqueado por López Rega y Lastiri, dos enemigos de la Tendencia. El presidente fue categórico en sus términos. Además de amenazar con una represión fuera de la ley si no se votaba el proyecto, les espetó: "Nadie está obligado a permanecer en una fracción política. El que no está contento, se va. (...) Quien esté en otra tendencia diferente de la peronista, lo que debe hacer es irse. En ese aspecto hemos sido muy tolerantes con todo el mundo. El que no está de acuerdo o al que no le conviene, se va" (Perón, 1974b: 36; véase también Bufano y Teixido, 2015: 235-241; Yofre, 2010: 258-267). 
47 Extra, febrero de 1974, p. 5. En la reunión con los diputados de la Tendencia Perón había expresado que el que estaba con los intereses guerrilleros "se saca la camiseta peronista y se va. Nosotros por perder un voto no vamos a ponernos tristes” (https://www.youtube.com/watch?v=fIsPpgSZTio).

48 Bernardo Neustadt, "Córdoba: se apaga la luz de la 'Patria Socialista”, Extra, marzo de 1974, p. 13.

49 Uno de los títulos de tapa de la edición de mayo se preguntaba: “Perón se enojó ¿y ahora?". La idea de “enojo”, y de cierto arrebato emocional excesivo por parte de Perón, aparecía nuevamente recuperada en las notas sobre el tema, justificada tanto por el tenor del desafío que había sufrido el presidente de parte de Montoneros como por los cánticos dirigidos contra su esposa y vicepresidenta, Isabel Perón. Esta idea de “arrebato" dejaba lugar a la duda sobre si era o no el final de la relación. Luego de la muerte de Perón el $1^{\circ}$ de julio de 1974, Neustadt llegó a preguntarse si el desgaste de este conflicto no había tenido consecuencias en su salud: “¿Lo mataron los disgustos de sus frenéticos adictos que tanto trataron de heredarle en vida? Dios dirá” (Bernardo Neustadt, "El día que murió Perón”, Extra, julio de 1974, p. 5).

50 Bernardo Neustadt, “¿Fin de una delicada relación?”, Extra, mayo de 1974, p. 15. Frente al “día difícil” que había significado el $1^{\circ}$ de mayo Extra quiso recoger sus ecos y entrevistó al sacerdote Carlos Mugica, al dirigente sindical Cesáreo Melgarejo y a hombres del quehacer nacional como Pepe Peña, Pablo Gowland y Gregorio Chodos, Extra, "Extra Intimo", pp. 7-8.

51 Extra, "El destino cita a los argentinos", julio de 1974, p. 15.

52 Extra, "La situación del movimiento", julio de 1974, p. 4. 